\title{
ANALYSIS CALCULATION OF DEPRECIATION FIXED ASSETS ACCORDING TO FINANCIAL ACCOUNTING STANDARDS AND TAX LAWS AS WELL AS IMPACT ON TAXABLE INCOME IN PT. MASSINDO SINAR PRATAMA MANADO
}

\author{
Yuvita M. F Goni ${ }^{1}$, Novi Swandari Budiarso ${ }^{2}$ \\ ${ }^{1,2}$ Pendidikan Profesi Akuntansi, Fakultas Ekonomi dan Bisnis, Universitas Sam Ratulangi, Jl. Kampus Bahu, \\ Manado, 95115, Indonesia \\ Email: yuvita.goni@yahoo.com
}

\begin{abstract}
Calculation of depreciation fixed assets according to financial accounting standards using five methods: the straight-line method, declining balance method, sum of the years digit method, service hours method, and the unit of productions method. While according to taxation rules just only use two method: the straight-line method and the declining balance method. The differences in the use of depreciation methods according to financial accounting standards and tax rules will result in fiscal correction. According to the depreciation expense is deductible expense for purpose of calculating income tax. The purpose of this study was determine the application of methods of depreciation fixed assets according to financial accounting standards and tax laws as well as impact on taxable income PT. Massindo Sinar Pratama Manado. The analytical method used is descriptive qualitative analysis method. The results showed the application of the method of calculation of depreciation PT. Massindo Sinar Pratama Manado in accordance with the provisions of the tax, but an error in the calculation of depreciation that increase the value of the company taxable income. PT. Massindo Sinar Pratama Manado should be more careful and referring to the tax rules in calculating the value of depreciation due to give effect to net profit before tax (taxable income) of the company, so that it will also to give effect to income tax to be paid by the company.
\end{abstract}

Keywords : depreciation, fixed assets, financial accounting standards, tax rules, taxable income

\section{INTRODUCTION}

In carrying out its operational activities every company will not be separated from the use of fixed assets, although the proportion of use of fixed assets is different from one company to another. In SFAS NO.16, the fixed assets are defined as tangible assets which are acquired in prepaid or built-in forms used in the operations of an enterprise, are not intended to be sold in the ordinary course of the enterprise and have a useful life of more than one year ". Nevertheless, the benefits provided by fixed assets generally decline further, and therefore should be calculated depreciation. Depreciation is the process of allocating part of the acquisition cost of an asset to an applicable cost as a deduction in determining or calculating profit. Thus, depreciation will affect the size of the profits derived from the calculation of commercial and fiscal profit / loss. The calculation of fixed asset depreciation expense is calculated using depreciation method in accordance with financial accounting standard (SAK) and taxation regulations. Differences in the use of depreciation calculation methods will have an impact on the income statement of the company. Differences in recognition of depreciation expenses according to financial (commercial) and taxation (fiscal) accounting standards, will result in fiscal correction. 
PT. Massindo Sinar Pratama Manado is a company engaged in manufacturing, especially in the industry bedding sector, where in carrying out its business activities the company uses various types of fixed assets such as machinery, vehicles, office inventory, and so will certainly experience depreciation. In calculating depreciation of its fixed assets the company must make a policy on depreciation method that will be used to calculate the depreciation value of fixed assets that have a limited useful life. The differences in the use of fixed asset depreciation method according to the financial accounting standard and according to the tax law will result in taxable profit calculated according to accounting (commercial) is different from the provisions of taxation (fiscal).

\section{LITERATURE REVIEWS}

\section{Accounting}

Accounting is an art of recording, classifying and summarizing in an informative and measured manner in the form of currency, on transactions or financial events of the firm and the interpretation of the results (Tanor, 2015). The overall purpose of accounting is to provide information that can be used in decision making (Tinungki, 2014).

\section{Financial Accounting}

Financial accounting is a process that ends in preparing financial statements concerning the company as a whole for use by both internal and external parties (Kieso, et al., 2011a: 5).

\section{Financial statements}

The financial statements is an information that describes the condition of a company, which then it will be an information that describes the performance of a company (Irham Fahmi 2011: 22). Complete financial statements usually include: Balance Sheet, Comprehensive Income Statement, Statement of Changes in Equity, Statement of Changes in Financial Position presented in the form of Cash Flow Statement or Fund Flow Report, Notes and Other Reports as well as explanatory materials that are an integral part of the financial statements.

\section{Fiscal Correction}

Fiscal correction is made when there is a difference between the standard, method or the accounting practices used in the preparation of commercial financial statements with fiscal financial statements (according to taxation provisions). The occurrence of differences between Financial Accounting Standards is due to the various interests of the state in utilizing tax as one component of fiscal policy. Fiscal correction involves the recognition of revenues and costs that may be positive correction and Negative correction (Nurchayati, 2016). Positive correction due to commercial depreciation is greater than fiscal depreciation; Negative correction due to commercial depreciation is less than fiscal depreciation (Kartini, 2012).

\section{Fixed assets}

Fixed assets are tangible assets or property of a company, with relatively high economic value, used for operational activities to produce goods and services with a period of usage periods expected over one year period (Christovin, 2015). Fixed assets are assets with properties that cannot be converted into cash in the operating cycle of a company (Pontoh, 2016).

From the above definition can be drawn the conclusion that the asset can be said fixed assets if it has the following characteristics:

1. Form a physical form

2. Be permanent or long term

3. Used in corporate operations

4. Not intended to be sold to consumers 


\section{Has a benefit value over a period of more than one year Depreciation of Fixed Assets}

Understanding depreciation according to Statement of Financial Accounting Standards (PSAK) No. 16 (2011: 15): "Depreciation is the allocation of the cost of a fixed asset over its economic life in a systematic and rational manner."

According to Winston Pontoh (2013: 358) over time the use of a fixed asset, at the same time fixed assets will begin to decrease in ability or begin experiencing obsolescence (obsolescence) to create goods and services. The decrease in fixed assets capability is referred to as depreciation. Depreciation generally occurs when a fixed asset is used and is a burden for the period in which the asset is utilized. Depreciation is made because the useful life and potential of the assets are saturated (Hery, 2014: 138). The amount of depreciation is the cost of an asset, or any other amount that replaces the cost, less the residual value. Depreciation is the systematic allocation of the amount of depreciable assets over its useful life. In financial accounting, depreciation of property and equipment is calculated monthly and for tax purposes depreciation is calculated only once - at the end of the reporting year (Tuhari, 2014). Thus, depreciation of property and equipment may be characterized as: the gradual transfer of fixed assets under the influence of the wear process on the cost or cost of the current period (Sigidov, 2016).

\section{Depreciation Method}

Hery (2014: 142) tangible fixed assets can be depreciated using several methods, certain types of depreciation methods for fixed assets applicable in Indonesia are:

1. Straight line method,

2. Sum of the years digit method,

3. Double declining balance method,

4. Service hours method, and

5. Unit of production method.

\section{Depreciation Method Based on Taxation Regulation}

Depreciation methods allowed under fiscal provisions are:

1. Straight Line Method

In the fiscal terms of this method is called depreciation in equal parts during the useful life defined as property.

2. Double declining balance method

Depreciation of tangible property is carried out in the declining portion over the useful life, calculated by applying the depreciation rate on the book value, and at the end of the useful life of the book value is depreciated on a condition that is consistent with the principle. Law Number 36 Year 2008 Article 11 concerning Income Tax explains that depreciation commences on the month of expenditure / acquisition of fixed assets / assets, except for assets still in progress, the depreciation begins on the month of completion of the work of the property. It states that, there is no date limit in charging depreciation, although the earnings are on $30^{\text {th }} / 31^{\text {st }}$ at the end of the month. This is in contrast to commercial depreciation where some companies make accounting policies impose depreciation in the next month if the acquisition is above the $15^{\text {th }}$ (Setiawati, 2012).

According to the tax regulations as stipulated in the provisions of the Taxation Law Article 11 of the Income Tax Law, in calculating the depreciation value of fixed assets Taxpayers may use the method of straight-line depreciation or declining balance method decreased. Taxpayers are permitted to choose one method for depreciation. Straight-line method is permissible for all groups of tangible fixed assets. While the declining balance method is only allowed to be used for tangible property groups instead of buildings alone, Mardiasmo (2016: 188). 
The following table illustrates the grouping of tangible assets, methods, and depreciation rates:

Table 1

Group and Depreciation Rate of Tangible Property

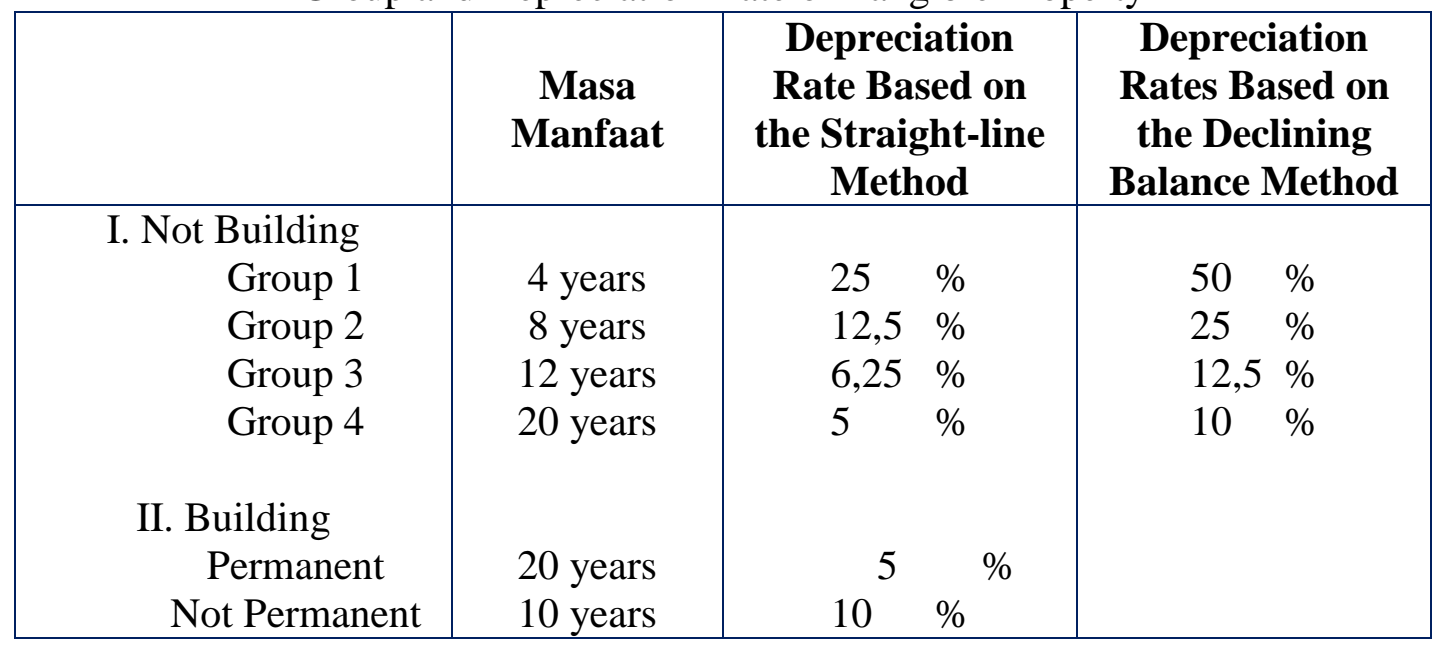

Grouping the types of tangible property, as Decree of the Minister of Finance No. 96 / PMK.03 / 2009. Types of tangible property not buildings not listed in Appendix I (Group 1), Appendix II (Group 2), Appendix III (Group 3), and Appendix IV (Group 4), for the purposes of depreciation are used in benefit periods in Group 3 as referred to in article 1 paragraph (1). Excluded from the provisions of paragraph (1), a taxpayer may obtain a fixed term of useful life for non-building property types in accordance with actual useful life, by means of Taxpayer Tax must file a request to the Director General of Taxation by indicating the actual useful life of the type - type of tangible property is not a building. And if the Taxpayer's application is rejected, then the Taxpayer uses the useful life of the tangible property type not the building as meant in paragraph (1), ie using the useful life in group 3.

\section{Income tax}

Taxes as expenses will affect the amount of profit received or that will be returned to shareholders (Ratag, 2013). Taxes are an important source revenue that will be used to finance state expenditures, both routine expenditures and development expenditures. Conversely for the company, the tax is a burden that will reduce net income (Sondakh, 2015). The Directorate General of Taxes (2013: 4) defines the tax as a compulsory contribution to a country that is indebted by an individual or a coercive body under the Act, by not obtaining direct remuneration and used for state purposes for the greatest possible prosperity of the people.Income tax $(\mathrm{PPh})$ is levied against the Person and the Agency, in respect of the income received or accrued during one tax year (Manengkey, 2015). Mardiasmo (2011: 135) defines the Income Tax (PPh) as follows: Income Tax is the tax imposed on the subject of tax (individual, body, permanent establishment) of income received or earned in the tax year. In accordance with SAK no.46 income tax is the tax calculated under the taxation rules and this tax is levied on the taxable income of the enterprise.

According to Wikipedia Bahasa Indonesia, "income tax is a tax imposed on the income of an individual, corporation or other legal entity." Thus the definition of income tax is an official levy directed to the income society or on income received and obtained in the tax year for the purposes of the State and society in the life of nation and state as a duty that must be implemented. In Act Number 7 of 1983 on Income Tax (PPh) which has been amended by Act Number 7 of 1991, Law Number 10 of 1994, Law No. 17 of 2000 and most recently amended by Law No. 36 of 2008 regulates the tax on income received or obtained by 
private persons or entities. Income Tax is levied on a Tax Subject in respect of the income received or accrued in the tax year. The tax subject is taxed if receiving or obtaining income. According mardiasmo (2011: 135) "the subject of taxes that receive or earn income, in the Law of Income referred to the Taxpayer". The taxpayer is taxed on the income earned during a tax period or may also be taxed for income in the taxable year part if his subjective tax obligations are incurred or expired in the tax year.

\section{Previous Research}

Sendow (2009), entitled Analysis of Fixed Assets Depreciation Calculation According to Financial Accounting Standards and Tax Law and Impact on Taxable Income at PT. ABC In Manado, the objective is to know the application of fixed assets depreciation method according to Financial Accounting Standards and Taxation Law applied to PT. ABC in Manado and its impact on taxable income. The results show that there is a difference in the calculation of taxable income between fiscal and commercial fiscal reports due to differences in the application of depreciation rates and estimated useful life between fiscal and commercial. Christovint (2015), entitled Evaluation of Calculation of Depreciation of Fixed Assets According to Taxation Regulation and Its Influence on Income Tax at PT. Bank Tabungan Negara (Persero) Tbk Manado Branch Office, its purpose to know how the application of depreciation method and the effect of calculation of depreciation to income tax at PT. Bank Tabungan Negara (Persero) Tbk Manado Branch Office. The results showed the application of calculation method of depreciation of PT. Bank Tabungan Negara (Persero) Tbk Manado Branch Office has been in accordance with taxation perraturan but there is a mistake in the calculation of depreciation so as to increase the value of corporate income tax.

\section{RESEARCH METHOD}

\section{Types of research}

This study uses descriptive-quantitative method, which is a method used based on data collected during systematic research on the facts and what actually appears from the object under study so as to provide a clear and true picture of the object under study, Sugiyono $(2013: 29)$.

\section{Data source}

Sunyoto (2013: 21), states that data collection can use two sources, namely primary source and secondary source. The data used in this study is the primary data which is data obtained directly from the object of research to be studied. The author examines directly on the object of research by compiling a list of questions, conducting interviews directly with employees and also the leader of the research object, namely PT. Massindo Sinar Pratama.

\section{Analysis Method}

The method of analysis used in this research is descriptive analysis. Descriptive research is a method that aims to describe a state of the company systematically, actual and accurate by collecting data based on data that appear in the company or organization, where the facts are collected, processed and analyzed so that further can be taken a conclusion and provide advice on Calculation Analysis of Depreciation of Fixed Assets According to Financial Accounting Standards and Tax Law and Impact on Taxable Income at PT. Massindo Sinar Pratama Manado.

\section{RESULTS AND DISCUSSIONS \\ Research result}

Based on the results of research conducted at PT. Massindo Sinar Pratama Manado, the company calculates depreciation using the Decrease Balance depreciation method to calculate vehicle depreciation, office inventory, plastic equipment and machinery. As for the calculation of depreciation of corporate buildings using the method of straight line 
depreciation. Depreciation rates are in accordance with company policy of $25 \%$ for vehicles, office inventory and plastic equipment. $12.5 \%$ for the machine. And $5 \%$ for buildings.

Table 1. List of Depreciation of Fixed Assets 2016

\begin{tabular}{|c|c|c|c|c|c|c|}
\hline Asset Type & Acquisition cos & $\%$ & Book Value 2015 & $\begin{array}{l}\text { Depreciation } \\
\text { Cost } 2016\end{array}$ & $\begin{array}{c}\text { Accumulated } \\
\text { Depreciation } 2016\end{array}$ & Book Value 2016 \\
\hline Vehicle & $4.142 .425 .128,00$ & $25 \%$ & $899.838 .272,65$ & $224.959 .568,16$ & $3.467 .546 .423,51$ & $674.878 .704,49$ \\
\hline $\begin{array}{l}\text { Office } \\
\text { Inventory }\end{array}$ & $340.799 .580,00$ & $25 \%$ & $36.224 .580,99$ & $9.056 .145,25$ & $313.631 .144,26$ & $27.168 .435,74$ \\
\hline $\begin{array}{l}\text { Plastic } \\
\text { Equipment }\end{array}$ & $216.190 .720,00$ & $12,5 \%$ & $86.186 .860,31$ & $21.546 .715,08$ & $151.550 .574,77$ & $64.640 .145,23$ \\
\hline $\begin{array}{l}\text { Foam } \\
\text { Machine }\end{array}$ & $446.365 .989,00$ & $12,5 \%$ & $174.877 .238,02$ & $21.859 .654,90$ & $293.348 .405,74$ & $153.017 .583,26$ \\
\hline Sofa Machine & $85.865 .443,00$ & $12,5 \%$ & $7.761 .816,47$ & $970.227,06$ & $79.073 .853,59$ & $6.791 .589,41$ \\
\hline $\begin{array}{l}\text { Plastic } \\
\text { Machinery }\end{array}$ & $3.092 .615 .590,00$ & $12,5 \%$ & $423.863 .901,22$ & $52.982 .987,65$ & $2.721 .734 .676,43$ & $370.880 .913,57$ \\
\hline $\begin{array}{l}\text { Spring Bed } \\
\text { Machine }\end{array}$ & $189.873 .206,00$ & $12,5 \%$ & $181.961 .822,42$ & $22.745 .227,80$ & $30.656 .611,39$ & $159.216 .594,61$ \\
\hline Buliding & $532.630 .050,00$ & $5 \%$ & $70.437 .162,09$ & $3.521 .858,10$ & $465.714 .746,02$ & $66.915 .303,98$ \\
\hline TOTAL & $9.046 .765 .706,00$ & & 1.881.151.654,17 & $357.642 .384,00$ & 7.523.256.435,69 & $1.523 .509 .270,31$ \\
\hline
\end{tabular}

Source: List of depreciation of PT. Massindo Sinar Pratama Manado Year 2016.

Table 1 shows the calculation of depreciation of PT. Massindo Sinar Pratama Manado in 2016

Table 2. Income Statement

\begin{tabular}{lr}
\hline \multicolumn{1}{c}{ Description } & Year \\
\cline { 2 - 2 } & \multicolumn{2}{c}{$\mathbf{2 0 1 6}$} \\
\hline Sales & 28.932 .311 .100 \\
HPP & 19.963 .294 .659 \\
Gross Profit & 8.969 .016 .659 \\
Administration \& Public Fee & 2.114 .488 .620 \\
Marketing Cost & 3.504 .353 .639 \\
Revenue (Expenses) Outside Bussiness & 121.703 .150 \\
Net Profit before Tax & 3.471 .877 .332 \\
\hline
\end{tabular}

Source: Income statement (loss) of PT. Massindo Sinar Pratama Year 2016

Table 2 shows that the profit earned in 2016 is Rp. 3,471,877,332. of the amount, the taxable income (income tax payable) that the company should pay is as follows:

Profit before tax:

Income tax payable: Rp. 3,471,877,332 x $25 \%$

Net profit after tax:

$$
\begin{aligned}
& =\text { Rp. } 3,471,877,332 \\
& =(\operatorname{Rp} \quad 867,969,333) \\
& =\text { Rp. 2.603.907.999 }
\end{aligned}
$$


From the calculation above is known that profit before tax (Taxable Income) obtained by the company in 2016 is Rp. 3,471,877,332 multiplied by $25 \%$ of income tax rate for corporate taxpayer since fiscal year 2010. Hence yielding value of Income amounting $\mathrm{Rp}$. 867.969.333. Thus, the net profit after tax obtained by PT. Massindo Sinar Pratama Manado in 2016 is Rp. 2.603.907.999.

\section{Discussion}

Calculation of depreciation in the financial statements must be based on the provisions of Financial Accounting Standards (SAK) and Tax Law. According to the Financial Accounting Standards the company can calculate the depreciation cost of fixed assets by using five methods of depreciation: straight line method, declining balance, annual number of hours, hours of service, and unit of production. While under the taxation provisions there are only two methods that a company can use to calculate the depreciation cost of its fixed assets, namely: the straight line method and the declining balance method. Specifically for calculating the method of calculation of depreciation used is the straight-line method. As for non-building property group, depreciation calculation can use straight-line method or declining balance method.

\section{Calculation of Depreciation of Fixed Assets PT. Massindo Sinar Pratama Manado By Taxation.}

Table 3. Depreciation of Fixed Assets According to the Taxation Regulation of 2016

\begin{tabular}{lrrrrrr}
\hline Asset Type & \multicolumn{1}{c}{ Acquisition cos } & \% & Book Value 2015 & $\begin{array}{c}\text { Depreciation } \\
\text { Cost 2016 }\end{array}$ & $\begin{array}{c}\text { Accumulated } \\
\text { Depreciation 2016 }\end{array}$ & Book Value 2016 \\
\hline Group 1 & $778.135 .036,00$ & $25 \%$ & $56.719 .895,75$ & $52.350 .465,75$ & $205.032 .433,00$ & $4.369 .430,00$ \\
Group 2 & $3.705 .089 .672,00$ & $12,5 \%$ & $1 / 012.193 .181,53$ & 358.454 .545 & $2.213 .897 .726,88$ & $653.738 .636,13$ \\
& & & & & & \\
Group 3 & $4.030 .910 .948,00$ & $6,25 \%$ & $776.088 .754,23$ & $200.892 .111,36$ & $2.631 .077 .138,14$ & 575.196 .642 \\
Building & $532.630 .050,00$ & $5 \%$ & $70.437 .162,09$ & $3.521 .858,10$ & $465.714 .746,02$ & $66.915 .303,98$ \\
TOTAL & $\mathbf{9 . 0 4 6 . 7 6 5 . 7 0 6 , 0 0}$ & & $\mathbf{1 . 9 1 5 . 4 3 8 . 9 9 3 , 6 0}$ & $\mathbf{6 1 5 . 2 1 8 . 9 8 0 , 5 8}$ & $\mathbf{5 . 5 1 5 . 7 2 2 . 0 4 4 , 0 4}$ & $\mathbf{1 . 3 0 0 . 2 2 0 . 0 1 2 , 9 7}$ \\
\hline
\end{tabular}

Source: Processed Data 2017

Table 3 shows the overall value of the acquisition cost of any assets owned by PT. Massindo Sinar Pratama Manado is Rp. 9,046,765,706.00. While the calculation results of depreciation of fixed assets according to tax regulations on PT. Massindo Sinar Pratama Manado 2016, calculated using the straight-line method. The calculation of depreciation cost of fixed assets in 2016 is Rp. 615,218,980,59, which consists of depreciation cost of group 1 of Rp. 52,350,465.75, the depreciation cost of group 2 is Rp. 358,454,545,38, the depreciation cost of group 3 is Rp. 200,892,111,36, and the depreciation cost of the building is Rp. 3,521,858.10. When compared with the calculation of depreciation of fixed assets based on the company's internal policies there are differences. Where according to the calculation of the company, the cost of depreciation of fixed assets in 2016 is Rp. 357.642.384.00. For a clearer explanation, the following shows the difference in the cost of depreciation of fixed assets according to the calculation of PT. Massindo Sinar Pratama Manado and in accordance with the provisions of taxation in 2016. 
Table 4. Difference in Value of Depreciation Fixed Assets PT. MSP Year 2016 Value Depreciation cost

\begin{tabular}{ccc}
\hline Commercial & Fiscal & Value \\
\hline $357.642 .384,00$ & $615.218 .980,59$ & $257.576 .596,59$ \\
\hline
\end{tabular}

Source: Processed Data 2017

Table 5 above shows the value of depreciation expense according to the calculation of PT. Massindo Sinar Pratama Manado in 2016 is Rp. 357.642.384,00, while the calculation according to the provisions of taxation is Rp. 615.218.980,59, then obtained the difference in value of depreciation (negative correction) of Rp. 257.576.596,59. Depreciation value according to taxation (fiscal) is greater than depreciation value according to the calculation of PT. Massindo Sinar Pratama Manado. From the calculation result according to the taxation provision obtained the difference of the depreciation expense which can add depreciation expense which has been recognized in profit and loss according to company calculation (commercial) so that become bigger if seen fiscally, thereby it will minimize the taxable income of company. For more details, the following are presented in the statements of income under the terms of taxation (fiscal).

Table 5. Income Statement

\begin{tabular}{lr}
\hline \multicolumn{1}{c}{ Depreciation } & Year \\
\cline { 2 - 2 } & $\mathbf{2 0 1 6}$ \\
\hline Sales & $28.932 .311 .100,00$ \\
HPP & $20.177 .840 .617,00$ \\
Gross Profit & \\
Administrative \& Public Fee & $2.140 .246 .280,59$ \\
Marketing Cost & $3.581 .626 .617,00$ \\
Revenue (Expenses) Outside Bussiness & $121.703 .150,00$ \\
Net Profit before Tax & $3.154 .300 .735,41$ \\
\hline
\end{tabular}

Source: Processed Data 2017

From the income statement (fiscal) above can be seen the cost of depreciation of fixed assets allocated in accordance with the use of each - the same part as in the statements of income (commercial), ie in accordance with company policy of $60 \%$ of the total cost of depreciation of fixed assets for the production , 30\% of the total depreciation cost of fixed assets for marketing, and $10 \%$ of the total depreciation cost of fixed assets for the adm \& general section. From the income statement above can also be seen that the profit earned by PT. Massindo Sinar Pratama Manado in 2016 is Rp. 3.154.300.735,41.

\section{Income Tax PT. Massindo Sinar Pratama}

Law no. 7 of 1984 concerning Income Tax is effective since January 1, 1984. This law has been amended several times and was last amended by Law No. 36 of 2008. The Income Tax Law regulates the imposition of Income Tax on the subject of tax in respect of the income received or earned in the tax year. The tax subject that receives or earns income, in the Income Tax Law is called a Taxpayer. The taxpayer is taxed on the income received or accrued during the tax year or may also be taxed for income in that portion of the tax year if his subjective tax obligations are incurred or expired in the taxable year, Mardiasmo (2016: 163). According to PPh article 17 (2a) Law no. 36 of 2008 regarding the imposition of corporate income tax rate in effect since fiscal year 2010 amounted to $25 \%$.

From the income statement above can be seen that the profit before tax (Taxable Income) obtained by PT. Massindo Sinar Pratama Manado in 2016 is Rp. 3.154.300.735,41. 
From the amount, it can be calculated the value of income tax (income tax payable) based on the depreciation value of fixed assets according to the calculation of taxation to be paid companies are as follows:

$\begin{array}{lll}\text { Profit before tax: } & & \text { Rp. 3.154.300.735, 41 } \\ \text { Income tax payable: Rp. } 3.154 .300 .735,41 \times 25 \% & = & \frac{(\mathrm{Rp} 788,575,183,852)}{\text { Rp. 2.365.725.551, 56 }} \\ \text { Net profit after tax: } & = & \end{array}$

From the above calculation is known profit before tax (Taxable Income) based on the value of depreciation of fixed assets according to the calculation of taxes obtained by the company in 2016 is Rp. 3.154.300.735,41 multiplied by $25 \%$ of income tax rate for corporate taxpayer since fiscal year 2010. Hence yield value of PPh equal to Rp. 788.575.183,825. Thus, the net profit after tax obtained by PT. Massindo Sinar Pratama Manado in 2016 is Rp. $2,365,725,551,56$. Difference in the cost of depreciation of fixed assets under the taxation regulation at PT. Massindo Sinar Pratama Manado adds depreciation cost to operating expenses in the company's performance report, thereby reducing the value of taxable income (net income before tax) resulting in an outstanding income tax value (PPh) less than the previous calculation in accordance with the company's (commercial) policy. The difference in the value of the income tax payable is due to the increase in depreciation charges calculated in accordance with the tax regulations. With the increase in depreciation expense of fixed assets, it also increases the total cost (expense) of the business in the company's performance report and minimize the profit before tax (taxable income) from the previous calculation.

\section{CONCLUSION}

The conclusions in this study are:

1. Application of calculation method of depreciation of fixed assets of PT. Massindo Sinar Pratama Manado is in accordance with the provisions of taxation. However, there are differences in classification, useful life, and fixed asset depreciation rates between company policies and tax regulations.

2. Differences in classification, useful life, and fixed asset depreciation rates between corporate policies and taxation laws result in a discrepancy between commercial and fiscal profit, which would affect the value of the income tax payable.

3. Calculation of depreciation of fixed assets according to taxation regulations at PT. Massindo Sinar Pratama Manado adds the cost of depreciation of fixed assets in the company's performance report, thereby reducing the value of taxable income (net income before tax) resulting in an outstanding income tax value $(\mathrm{PPh})$ less than the previous calculation in accordance with company policy. The value of taxable income of PT. Massindo Sinar Pratama Manado in 2016 for Rp. 3,471,877,332. While the value of taxable income according to the provisions of taxation (fiscal) of Rp. 3.154.300.735,41. There is a difference (Positive Correction) of Rp. 317.576.596,59.

Suggestions can be given, as follows:

1. The company must be more rigorous and refers to taxation regulations in calculating the cost of depreciation of fixed assets because these costs will affect the net profit before taxes (taxable income) of the company so that it will also affect the value of income tax payable to be paid by the company.

2. In calculating depreciation of fixed assets, the Company shall follow the tariff and estimated useful life of the assets in accordance with the taxation rules of Article 11 of Law Number 17 Year 2000 and the Regulation of the Minister of Finance Number 96 / PMK.03 / 2009 concerning the types of assets belonging to the group tangible property is not a building for the purpose of depreciation, so there is no need for fiscal correction to calculate depreciation cost 


\section{REFERENCES}

Christovint., Sondakh, Jullie. J., Sabijono Harijanto., 2015, "Evaluasi Perhitungan Penyusutan Aktiva Tetap Menurut Peraturan Perpajakan Serta Pengaruhnya Terhadap Pajak Penghasilan (PPh) Pada PT. Bank Tabungan Negara (Persero) Tbk Kantor Cabang Manado" Jurnal Berkala Ilmiah, 15(05), 144-154.

Dewi, M. S., Setiawati, Hana., 2012, "Analisis Dampak Perubahan UU Pajak Penghasilan Terhadap Besarnya Pajak Penghasilan Pada PT. JAJ" BINUS BUSINESS REVIEW, 2(2), 949-964.

Diana Anastasia, Lilis S. 2010. Perpajakan Indonesia: Konsep, Aplikasi, \& Penuntun Praktis. Edisi 3. Andi: Yogyakarta.

Direktorat Jendral Pajak. 2013. Ketentuan Umum dan Tata Cara Perpajakan. Direktorat Jendral Pajak. Jakarta.

Direktorat Jendral Pajak. 2013. Pajak Penghasilan. Direktorat Jendral Pajak. Jakarta.

Fahmi, Irham. 2012. Manajemen Risiko. Bandung: Alfabeta.

Hery. 2014. Akuntansi Aset, Liabilitas, dan Ekuitas.Penerbit PT. Gramedia Widiasarana Indonesia. Jakarta.

Hery. 2015. Analisis Laporan Keuangan. Penerbit CAPS (Center for Academy Publishing Service). Yogyakarta.

Kartini, Popi Surita., 2012, "Pengaruh Penyusutan Aktiva Tetap Terhadap Laba Dan Penghematan Pajak Pada PT. Kukar Mandiri Shipyard" Jurnal Ilmiah, 1(1), 1-5.

Kieso, Donald E., Weygandt, Jery J., Warfield. 2010. Akuntansi Intermediate. Terjemahan Emil Salim. Jilid I. Edisi Kesepuluh. Erlangga. Jakarta.

Manengkey, Speny Ria., Pangemanan, Sifrid., Pontoh, Winston., 2015, "Dampak Pemahaman Wajib Pajak Atas PP Nomor 46 Tahun 2013 Terhadap Penerimaan Pajak Penghasilan Pasal 21 Pada KPP Pratama Kotamobagu." Jurnal Accountability, 4(1), $1-9$.

Mardiasmo. 2011. Perpajakan, Edisi Revisi. Andi: Yogyakarta.

Mardiasmo. 2016. Perpajakan, Edisi Revisi. Andi: Yogyakarta.

Pontoh, Eleanor Laura., Morasa, Jenny., Budiarso, Novi. S., 2016, "Evaluasi Penerapan Perlakuan Akuntansi Terhadap Aktiva Tetap Berdasarkan PSAK No. 16 Tahun 2011 Pada PT. Nichindo Manado Suisan." Jurnal EMBA, 4(3), 068-077.

Pontoh, Winston, 2013 Akuntansi Konsep dan Aplikasi,Jakarta Barat; Halaman Moeka.

Ratag, G. A., 2013, "Perencanaan Pajak Melalui Metode Penyusutan Aktiva Tetap Untuk Menghitung PPh Badan Pada PT. Bank Sulut.” Jurnal EMBA, 1(3), 950-958.

Rismawani, A. T., Nurchayati., 2016, “Analisis Koreksi Fiskal Atas Laporan Keuangan Komersial Dalam Penentuan Pajak Penghasilan Pada PT. Gajah Mada Indra Sehati (Hotel IBIS Simpang Lima Semarang)" Jurnal Ilmiah UNTAG Semarang, 5(1), 7383.

Sigidov, Yuriy. I., Rybyantseva, Maria. S., Adamenko, Alexandr. A., Yarushkina, Elena. A., 2016, "Methodological Aspects of Depreciation as an Economic Category." International Journal of Economics and Financial Issues, 6(SI), 88-95.

Sondakh, Steffani Gabriella., 2015, "Analisis Koreksi Fiskal Atas Laporan Keuangan Komersial Pada PT. Bank Perkreditan Rakyat Cipta Cemerlang Indonesia.” Jurnal EMBA, 3(4), 357-368.

Sugiyono, 2012. Metode Penelitian. Alfabeta. Bandung..

Tuhari, Tudor., Gutan, Viorica., 2014, "Accounting And Tax Depreciation Of Fixed Assets: Methodological Problems And Ways To Solve Them.” Journal of Research on Trade, Management and Economic Development, 1(1), 77-83. 